\title{
Nitrate supplementation of rations based on rice straw but not Pangola hay, improves growth performance in meat goats
}

\author{
Siwaporn Paengkoum ${ }^{1, *}$, Jiravan Khotsakdee ${ }^{2,3}$, Pramote Paengkoum $^{3}$, \\ Thomas Schonewille ${ }^{2,4}$, and Chalermpon Yuangklang ${ }^{2, *}$
}

\footnotetext{
* Corresponding Authors:

Siwaporn Paengkoum

Tel: +66-815926658,

E-mail: took_sw@yahoo.com

Chalermpon Yuangklang

Tel: +66-819844312,

E-mail: chalermpon.yu@rmuti.ac.th

${ }^{1}$ Faculty of Science and Technology, Nakhon Ratchasima Rajabhat University, Nakhon

Ratchasima 30000, Thailand

2 Faculty of Sciences and Liberal Arts,

Rajamangala University of Technology Isan,

Nakhon Ratchasima 30000, Thailand

${ }^{3}$ School of Animal Technology and

Innovation, Suranaree University of

Technology, Nakhon Ratchasima, 30000,

Thailand

${ }^{4}$ Department of Farm Animal Health, Faculty

of Veterinary Medicine, Utrecht University,

Utrecht 3584, The Netherlands

ORCID

Siwaporn Paengkoum

https://orcid.org/0000-0001-8529-3452

Jiravan Khotsakdee

https://orcid.org/0000-0001-8318-1377

Pramote Paengkoum

https://orcid.org/0000-0003-4007-9000

Thomas Schonewille

https://orcid.org/0000-0002-8204-0684

Chalermpon Yuangklang

https://orcid.org/0000-0002-3844-1691
}

Submitted Apr 23, 2020; Revised Jun 22, 2020; Accepted Jul 28, 2020
Objective: Supplemental nitrate is known to be an effective tool to mitigate methane emission by ruminants. Based on theoretical considerations, supplemental nitrate can improve but also deteriorate the growth performance. The overall effect of supplemental nitrate on growth performance, however, is not yet known. The objective of the current study was therefore to evaluate the effect of a higher dose of $\mathrm{NO}_{3}^{-}$on overall growth performance when feeding either Pangola grass hay or rice straw.

Methods: Thirty-two crossbred, 3-month-old Thai nativexAnglo-Nubian crossbred male goats were used. The experiment had a $2 \times 2$ factorial design with an experimental period of 60 days. Eight goats were randomly allocated to each dietary treatment, i.e. a ration containing either Pangola hay (Digitaria eriantha Steud) or rice straw (Oryza Sativa) as a source of roughage, supplemented with a concentrate containing either $3.2 \%$ or $4.8 \%$ potassium nitrate. The rations were formulated to be isonitrogenous. The animals were weighed at the start of the experiment and at days 30 and 60 . Feces were collected during the last five days of each 30-day period.

Results: High-nitrate increased overall DM intake by approximately 3\%, irrespective the source of roughage, but only the goats fed a rice straw-based ration responded with an increase in body weight (BW). Thus, the overall feed conversion ratio ( $\mathrm{kg}$ feed/ $\mathrm{kg}$ BW gain) was influenced by roughage source $\times$ nitrate and decreased by almost $60 \%$ when the goats were fed rice straw in combination with a high versus a low dietary nitrate content. The digestibility of macronutrients was only affected by the source of roughage and the digestibility of organic matter, crude protein, and neutral detergent fibre was greater when the goats were fed Pangola hay.

Conclusion: It was concluded that the replacement of soybean meal by nitrate improves the growth performance of meat goats fed rations based on rice straw, but not Pangola hay.

Keywords: Nitrate; Rice Straw; Pangola Hay; Digestibility; Goats

\section{INTRODUCTION}

Enteric methane $\left(\mathrm{CH}_{4}\right)$ is a potent greenhouse gas and the emission that originates from ruminant production is considered relevant [1]. The vast majority of $\mathrm{CH}_{4}$ production by ruminants is caused by the anaerobic fermentation of organic matter $(\mathrm{OM})$ in the rumen [2] because the synthesis of volatile fatty acids is inevitably associated with that of hydrogen and therefore of $\mathrm{CH}_{4}$ [3].

Nitrate $\left(\mathrm{NO}_{3}^{-}\right)$has been shown to effectively suppress $\mathrm{CH}_{4}$ methane production [4-6] because $\mathrm{NO}_{3}{ }^{-}$can be reduced to ammonia $\left(\mathrm{NH}_{3}\right)$ and therefore acts as a hydrogen sink [7]. Thus, in rations with limiting crude protein (CP) contents, supplemental $\mathrm{NO}_{3}^{-}$can be considered as an alternative source of nitrogen for microbial protein synthesis [8,9]. Supplemental $\mathrm{NO}_{3}^{-}$can therefore potentially enhance animal production in $\mathrm{CP}$ limiting rations 
and at same time reduce methane emission. On the other hand, the process of $\mathrm{NO}_{3}{ }^{-}$reduction competes with ruminal propionogenesis [10] because propionate also, can act as a hydrogen sink [3]. There are indications that a $\mathrm{NO}_{3}{ }^{-}$induced redirection of energy to $\mathrm{NH}_{3}$ [11] instead of propionate, would not favor animal production [12] especially in the case where poor quality rations are fed. From this perspective, $\mathrm{NO}_{3}{ }^{-}$may not be suitable to mitigate methane emission because tropical roughages typically are of a poor quality [13]. The overall net effect of supplemental $\mathrm{NO}_{3}^{-}$on animal production, however, is difficult to predict.

To the best of the authors' knowledge however, there are currently no studies reporting on the effect of extra $\mathrm{NO}_{3}{ }^{-}$on the growth performance in meat goats. In Thailand, Pangola grass (hay) is the preferred type of roughage in goat nutrition because it is generally perceived as a high-quality roughage when compared to rice straw. The latter is typically fed during periods of feed scarcity. The objective of the current study was therefore to evaluate the effect of a higher dose of $\mathrm{NO}_{3}{ }^{-}$ on overall growth performance when feeding either Pangola grass hay or rice straw.

\section{MATERIALS AND METHODS}

\section{Ethical considerations}

The current experiment was approved by the Animal Ethics Committee of Suranaree University of Technology Isan (approval number, RU3-303-55-01) and based on the Ethics of Animal Experimentation of the National Research Council of Thailand.

\section{Animals, experimental design and housing}

Thirty-two crossbred, 3-month-old Thai native $\times$ AngloNubian crossbred male goats were used. The experiment had a $2 \times 2$ factorial design with an experimental period of 60 days. Eight goats were randomly allocated to each dietary treatment, i.e. a ration containing either Pangola hay (Digitaria eriantha Steud) or rice straw (Oryza sativa) as a source of roughage, supplemented with a concentrate containing either $3.2 \%$ or $4.8 \%$ potassium nitrate (Table 1 ). The experiment was preceded by a 14-day pre-experimental period in which the animals were fed a ration based on Pangola hay. Throughout the experiment, the goats were housed in individual pens with slatted floors and the animals had free access to fresh water and a mineral block.

\section{Experimental rations}

The roughages and concentrates were offered at $3.5 \%$ and $1.5 \%$ of body weight (BW), respectively, irrespective either source. The feedstuffs were offered daily in two equal portions at 08:00 and 16:00 h. Feed refusals, if present, were collected and weighed daily before the morning feeding so as to deter-
Table 1. The ingredient and chemical composition of the experimental concentrates

\begin{tabular}{|c|c|c|}
\hline Items & $\begin{array}{l}\text { Low } \\
\text { nitrate }\end{array}$ & $\begin{array}{c}\text { High } \\
\text { nitrate }\end{array}$ \\
\hline \multicolumn{3}{|l|}{ Ingredient composition (\% as fed) } \\
\hline Dry cassava distiller's meal & 32.0 & 35.0 \\
\hline Dry corn distiller's grains & 15.0 & 12.0 \\
\hline Rice bran & 10.0 & 10.0 \\
\hline Wheat bran & 10.0 & 10.0 \\
\hline Molasses & 7.0 & 7.0 \\
\hline Sunflower oil & 6.0 & 6.0 \\
\hline Soybean meal & 14.5 & 12.9 \\
\hline Potassium nitrate & 3.2 & 4.8 \\
\hline Premix ${ }^{1)}$ & 2.3 & 2.3 \\
\hline \multicolumn{3}{|l|}{ Analyzed composition } \\
\hline Dry matter (g/kg) & 922.0 & 921.5 \\
\hline Crude ash (g/kg DM) & 71.2 & 71.4 \\
\hline Crude protein (g/kg DM) & 153.4 & 153.4 \\
\hline Ether extract (g/kg DM) & 62.5 & 61.5 \\
\hline Neutral detergent fiber (g/kg DM) & 425.0 & 405.0 \\
\hline Acid detergent fiber (g/kg DM) & 263.0 & 256.5 \\
\hline Non-structural carbohydrates (g/kg DM) $)^{2)}$ & 288.0 & 308.4 \\
\hline \multicolumn{3}{|c|}{ 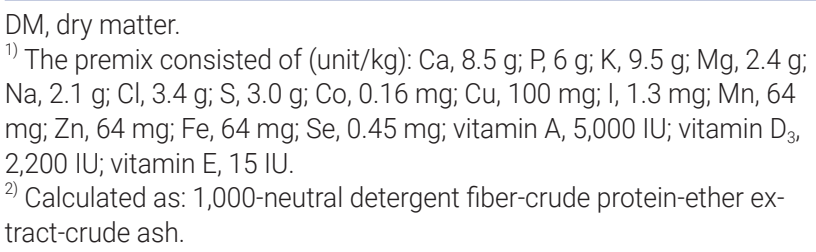 } \\
\hline
\end{tabular}

mine the actual daily feed intake. The animals were weighed at the start of the experiment and at days 30 and 60 so as to monitor BW and to adjust the amounts of feed offered. Within the two 30-day periods, each individual animal was therefore offered a fixed amount of dry matter (DM).

Pangola grass was harvested after 45 days of regrowth and sun dried for 5 days. After drying, the moisture content was found to be $125 \mathrm{~g} / \mathrm{kg}$ and the DM had the following chemical composition (g/kg): crude ash, 84; CP, 73; ether extract (EE), 19; neutral detergent fiber (NDF), 734; acid detergent fiber (ADF), 359. The rice straw, with a moisture content of $78 \mathrm{~g} / \mathrm{kg}$, was chemically composited as follows (g/kg DM): crude ash, 123; CP, 33; EE, 10; NDF, 734; ADF, 523. The ingredient and chemical composition of the experimental rations is shown in Table 2. The values on the chemical composition in Table 2 are based on the actual mean DM intakes of the experimental feedstuffs as calculated over the 60 days.

\section{Collection of samples}

The experimental feedstuffs were sampled on the last five days of each 30-day period of the experiment. Then, the feedstuff samples were dried at $70^{\circ} \mathrm{C}$ for 72 hours, ground to pass a 1 $\mathrm{mm}$ sieve, pooled across the 5 sampling days and subsequently stored in sealed plastic bags at ambient temperature $\left(25^{\circ} \mathrm{C}\right)$ until analysis. Feces also were collected during the last five 
Table 2. The ingredient and chemical composition of the experimental rations ${ }^{1)}$

\begin{tabular}{|c|c|c|c|c|}
\hline \multirow{2}{*}{ Items } & \multicolumn{2}{|c|}{ Pangola hay } & \multicolumn{2}{|c|}{ Rice straw } \\
\hline & Low nitrate & High nitrate & Low nitrate & High nitrate \\
\hline \multicolumn{5}{|c|}{ Ingredient composition (g DM/d) } \\
\hline Pangola hay ${ }^{2)}$ & 416 & 439 & - & - \\
\hline Rice straw $^{3)}$ & - & - & 394 & 410 \\
\hline Concentrate, low nitrate & 253 & - & 242 & - \\
\hline Concentrate, high nitrate & - & 252 & - & 245 \\
\hline Total intake & 669 & 692 & 637 & 656 \\
\hline \multicolumn{5}{|c|}{ Analyzed composition (g/kg DM) } \\
\hline $\mathrm{OM}$ & 920.8 & 920.6 & 896.7 & 896.3 \\
\hline $\mathrm{CP}$ & 103.4 & 102.4 & 78.8 & 78.2 \\
\hline $\mathrm{EE}$ & 35.4 & 34.5 & 30.0 & 29.3 \\
\hline NDF & 617.2 & 614.0 & 634.4 & 629.0 \\
\hline ADF & 322.7 & 321.6 & 424.1 & 423.3 \\
\hline $\mathrm{NSC}^{4)}$ & 164.8 & 169.7 & 153.6 & 159.8 \\
\hline Nitrate & 8.0 & 11.6 & 8.1 & 11.9 \\
\hline
\end{tabular}

days of each 30-day period. The feces from individual goats were quantitatively collected with the use of a plastic sheet which was spread below the slatted floors. The daily feces production of each goat was stored at $-18^{\circ} \mathrm{C}$. At the end of the 5 days collection period, the stored daily feces collections were thawed, mixed thoroughly and sampled. The samples were dried at $70^{\circ} \mathrm{C}$ for 72 hours, ground to pass a $1 \mathrm{~mm}$ sieve and stored in sealed plastic bags at ambient temperature $\left(25^{\circ} \mathrm{C}\right)$ until analysis.

\section{Chemical analysis}

The ash content of the experimental feedstuffs was analyzed by combustion at $600^{\circ} \mathrm{C}$ for 6 hours. Nitrogen contents were determined by the macro Kjeldahl method [14]; a factor of 6.25 was used to convert nitrogen into CP. The EEs of the feedstuffs were prepared according to the AOAC [14]; the solvent was evaporated, and the residue was weighed. The NDF and ADF contents of the rations were analyzed according to the method of [15] and the values are expressed without residual ash.

\section{Statistical analysis}

All data were subjected to analysis of variance using the general linear model procedure in SAS [16], using the model:

$$
Y_{i j}=\mu+R S_{i}+N_{j}+(R S \times N)_{i j}+e_{i j}
$$

where $\mathrm{Y}_{\mathrm{ij}}=$ a response variable (e.g. growth performance, nu- trient digestibility); $\mu$ = overall mean; $\mathrm{RS}_{\mathrm{i}}=$ roughage source ( $i=$ Pangola hay or rice straw); $F_{j}=$ level of dietary nitrate $(j$ $=$ low or high); $(\mathrm{RS} \times \mathrm{N})_{\mathrm{ij}}=$ interaction term between $\mathrm{RS}$ and level of nitrate; and $\mathrm{e}_{\mathrm{ij}}=$ residual error. Both, the RS and level of nitrate $(\mathrm{N})$ were set as fixed factors in the statistical model. Throughout, the level of statistical significance was pre-set at $\mathrm{p} \leq 0.05$.

\section{RESULTS}

\section{Growth performance}

During the first 30-day period, DM-intake was similar between treatments (Table 3) but the goats fed Pangola hay versus rice straw had a significantly $(\mathrm{p}<0.05)$ greater gain in BW (Table 3). Next to the source of roughage, BW was also affected by the nitrate content of the ration $(\mathrm{p}<0.05)$ but the effect of a high dietary nitrate content was only observed in the goats fed rice straw $(p<0.05)$. The growth rate of the goats was likewise affected by the dietary treatments $(p<0.05)$. The lowest values $(p<0.05)$ on the feed conversion ratio (FCR, $g$ feed/g gain) were found when the animals were fed Pangola hay but the FCR was not affected by the high dietary nitrate content. In contrast, the FCR of the goats fed rice straw was found to be $\sim 3$ times lower when the ration contained the high nitrate content.

During the second half of the experiment (i.e. from day 31 to day 60) the DM intake (Table 3) was affected by an interaction between RS and the nitrate content of the ration 
Table 3. Feed intake and growth performance in goats after the feeding of the experimental rations for 60 days

\begin{tabular}{|c|c|c|c|c|c|c|c|c|}
\hline \multirow{2}{*}{ Items } & \multicolumn{2}{|c|}{ Pangola hay } & \multicolumn{2}{|c|}{ Rice straw } & \multirow{2}{*}{ SEM } & \multicolumn{3}{|c|}{ p-value } \\
\hline & Low & High & Low & High & & RS & $\mathbf{N}$ & $\mathrm{RS} \times \mathrm{N}$ \\
\hline \multicolumn{9}{|l|}{ Day 1 to 30} \\
\hline Mean DM intake $(\mathrm{g} / \mathrm{d})$ & 623 & 622 & 615 & 620 & 8.0 & 0.526 & 0.847 & 0.708 \\
\hline \multicolumn{9}{|l|}{ Body weight $(\mathrm{kg})$} \\
\hline Initial & $17.4^{\mathrm{a}}$ & $17.6^{\mathrm{a}}$ & $16.8^{\mathrm{ab}}$ & $16.4^{b}$ & 0.22 & $<0.001$ & 0.609 & 0.204 \\
\hline Gain & $2.3^{\mathrm{a}}$ & $2.0^{\mathrm{a}}$ & $0.5^{c}$ & $1.3^{\mathrm{b}}$ & 0.08 & $<0.001$ & $<0.001$ & $<0.001$ \\
\hline Growth rate $(\mathrm{g} / \mathrm{d})$ & $75.0^{\mathrm{a}}$ & $67.9^{\mathrm{a}}$ & $15.6^{\mathrm{b}}$ & $43.3^{c}$ & 2.60 & $<0.001$ & $<0.001$ & $<0.001$ \\
\hline $\mathrm{FCR}^{1)}(\mathrm{kg} / \mathrm{kg})$ & $8.4^{\mathrm{b}}$ & $9.3^{b}$ & $45.0^{\mathrm{a}}$ & $14.8^{b}$ & 2.84 & $<0.001$ & $<0.001$ & $<0.001$ \\
\hline \multicolumn{9}{|l|}{ Day 31 to 60} \\
\hline Mean DM intake (g/d) & $717^{\mathrm{b}}$ & $761^{a}$ & $658^{c}$ & $691^{\mathrm{bc}}$ & 11.3 & $<0.001$ & 0.002 & 0.618 \\
\hline \multicolumn{9}{|l|}{ Body weight $(\mathrm{kg})$} \\
\hline Day 31 & $19.7^{\mathrm{a}}$ & $19.6^{\mathrm{a}}$ & $17.3^{\mathrm{b}}$ & $17.7^{b}$ & 0.22 & $<0.001$ & 0.391 & 0.307 \\
\hline Gain & $2.2^{\mathrm{a}}$ & $2.2^{\mathrm{a}}$ & $1.0^{\mathrm{c}}$ & $1.4^{\mathrm{b}}$ & 0.11 & $<0.001$ & 0.050 & 0.063 \\
\hline Growth rate $(\mathrm{g} / \mathrm{d})$ & $73.8^{a}$ & $74.2^{\mathrm{a}}$ & $31.7^{c}$ & $46.7^{b}$ & 3.77 & $<0.001$ & 0.050 & 0.063 \\
\hline FCR (kg/kg) & 9.8 & 10.4 & 48.5 & 14.9 & 11.26 & 0.070 & 0.162 & 0.148 \\
\hline \multicolumn{9}{|l|}{ Day 1 to 60} \\
\hline Mean DM intake (g/d) & $669^{\mathrm{ab}}$ & $692^{a}$ & $637^{c}$ & $656^{\mathrm{bc}}$ & 8.0 & $<0.001$ & 0.015 & 0.824 \\
\hline \multicolumn{9}{|l|}{ Body weight (kg) } \\
\hline Gain & $4.5^{\mathrm{a}}$ & $4.3^{\mathrm{a}}$ & $1.4^{\mathrm{c}}$ & $2.7^{\mathrm{b}}$ & 0.15 & $<0.001$ & 0.001 & $<0.001$ \\
\hline Final $^{2)}$ & $21.9^{\mathrm{a}}$ & $21.9^{\mathrm{a}}$ & $18.2^{\circ}$ & $19.1^{b}$ & 0.23 & $<0.001$ & 0.001 & $<0.001$ \\
\hline Growth rate $(\mathrm{g} / \mathrm{d})$ & $74.4^{\mathrm{a}}$ & $71.0^{\mathrm{a}}$ & $23.6^{c}$ & $45.0^{b}$ & 2.47 & $<0.001$ & 0.001 & $<0.001$ \\
\hline FCR $(\mathrm{kg} / \mathrm{kg})$ & $7.9^{\mathrm{b}}$ & $9.8^{\mathrm{b}}$ & $36.4^{\mathrm{a}}$ & $14.7^{\mathrm{b}}$ & 4.67 & 0.001 & 0.043 & 0.018 \\
\hline
\end{tabular}

SEM, standard error of the mean; DM, dry matter; FCR, feed conversion ratio.

1) Calculated as $\mathrm{kg} \mathrm{DM}$ feed/kg body weight gain.

2) Statistically analyzed using initial body weight as a covariate.

${ }^{a-c}$ Different superscripts indicate statistical difference within each row $(p<0.05)$

$(\mathrm{p} \geq 0.05)$. The greatest DM intakes $(\mathrm{p}<0.05)$ were observed when the goats were fed Pangola hay and the ration contained a greater amount of nitrate. The rice straw fed goats had a $\sim 11 \%$ lower BW at the start of the second half of the experiment and showed a lower gain in BW and growth rate compared to the goats fed Pangola hay $(\mathrm{p}<0.05)$. Compared to the first 30 days of the experiment, BW gain and growth rate were likewise affected by nitrate and the interaction between RS and the dietary nitrate content but the differences were only borderline statistically significant.

Table 4. Digestibility (\% of intake) of organic matter (OM), neutral detergent fibre (NDF), acid detergent fibre (ADF), and crude protein (CP) in goats after the feeding of the experimental rations for 60 days

\begin{tabular}{|c|c|c|c|c|c|c|c|c|c|}
\hline \multirow{2}{*}{ Items } & \multirow{2}{*}{$\begin{array}{r}\text { Roughage source (RS) } \\
\text { Level of nitrate }(\mathrm{N})\end{array}$} & \multicolumn{2}{|c|}{ Pangola hay } & \multicolumn{2}{|c|}{ Rice straw } & \multirow{2}{*}{ SEM } & \multicolumn{3}{|c|}{ p-value } \\
\hline & & Low & High & Low & High & & RS & $\mathbf{N}$ & $\mathrm{RS} \times \mathrm{N}$ \\
\hline \multicolumn{10}{|c|}{ Day 25 to 30} \\
\hline NDF & & $62.8^{\mathrm{ab}}$ & $64.7^{\mathrm{a}}$ & $58.6^{b}$ & $60.8^{\mathrm{ab}}$ & 1.51 & 0.012 & 0.191 & 0.922 \\
\hline $\mathrm{ADF}$ & & $49.5^{c}$ & $51.8^{b}$ & $56.2^{\mathrm{ab}}$ & $59.4^{\mathrm{a}}$ & 1.72 & $<0.001$ & 0.122 & 0.805 \\
\hline $\mathrm{CP}$ & & $64.1^{\mathrm{a}}$ & $63.2^{\mathrm{a}}$ & $52.9^{b}$ & $51.4^{b}$ & 1.99 & $<0.001$ & 0.548 & 0.879 \\
\hline NDF & & $67.8^{a}$ & $69.2^{a}$ & $62.9^{b}$ & $66.0^{\mathrm{b}}$ & 1.20 & 0.003 & 0.073 & 0.503 \\
\hline ADF & & $56.3^{b}$ & $58.0^{b}$ & $60.8^{a b}$ & $64.4^{a}$ & 1.44 & 0.001 & 0.088 & 0.508 \\
\hline $\mathrm{CP}$ & & $70.2^{a}$ & $68.4^{b}$ & $57.6^{\mathrm{b}}$ & $59.5^{b}$ & 1.89 & $<0.001$ & 0.974 & 0.350 \\
\hline \multicolumn{10}{|c|}{ Overall means } \\
\hline OM & & $75.5^{\mathrm{a}}$ & $75.5^{\mathrm{a}}$ & $70.3^{b}$ & $72.5^{\mathrm{ab}}$ & 0.97 & $<0.001$ & 0.263 & 0.275 \\
\hline
\end{tabular}

SEM, standard error of the mean; OM, organic matter; NDF, neutral detergent fibre; ADF, acid detergent fibre; CP, crude protein.

${ }^{a-c}$ Different superscripts indicate statistical difference within each row $(p<0.05)$ 
Overall, from day 0 to day 60 , the DM intake was only affected by both RS and the dietary nitrate content while the gain in BW, final BW and the growth rate were significantly affected by the interaction between RS and the dietary nitrate content. The overall FCR also was influenced by RS $\times$ nitrate and decreased by almost $60 \%$ when the goats were fed rice straw in combination with a high versus a low dietary nitrate content.

\section{Macronutrient digestibility}

Throughout the experiment, the digestibility of macronutrients (Table 4) was not affected by the interaction between RS and nitrate $(\mathrm{p}<0.05)$. The digestibility of NDF tended ( $\mathrm{p}=$ 0.073 ) to be affected by a high dietary nitrate content only in the second half of the experiment. The digestibility of ADF was likewise affected and across the two experimental periods, a high dietary nitrate content increased the ADF digestibility by almost 5 percentage units $(\mathrm{p}<0.05)$. The source of roughage significantly affected the digestibility's of $\mathrm{OM}, \mathrm{CP}$, and NDF and all values were found to be greater $(p<0.05)$ when the goats were fed Pangola hay. In contrast, the digestibility of $\mathrm{ADF}$ was greater $(\mathrm{p}<0.05)$ when the goats were fed rice straw instead of Pangola hay.

\section{DISCUSSION}

To the best of the our knowledge the current results are the first showing that a high versus a low dietary nitrate content improves the growth performance of meat goats fed rice straw. Interestingly, the high-nitrate induced improvement of FCR was not observed when the goats were fed Pangola hay (Table 3). Although FCR was systematically improved in goats fed the high-nitrate, rice straw-based rations, during the second half of the experiment the difference in FCR failed to reach statistical significance. The data however, are clearly in line with the FCR-values obtained from day 1 to 30 but the variation was aberrantly much greater when compared with the variation in FCR values during the first half of the experiment. It is therefore most likely that the probability of type-1 error was unfavourably affected by the high variation in FCR during the second half of the experiment.

The observed interaction between RS and high dietary nitrate is not easy to explain but the data are in line with the idea that nitrate enhances the growth of rumen bacteria and therefore renders a greater amount of microbial protein due to the reduction of $\mathrm{NO}_{3}^{-}$to $\mathrm{NH}_{3}$ in the rumen environment [17]. Although rations were formulated to be iso-nitrogenous within RS, the amount of $\mathrm{N}$ available for microbial growth was most likely not similar between the nitrate treatments because $\sim 15 \%$ of the protein in soybean meal is not degraded in the rumen environment [18] while virtually all nitrate is reduced to $\mathrm{NH}_{3}$ [19]. It is well established that there is a sharp increase in the growth rate of rumen microbes when the amount of available $\mathrm{N}$ becomes greater than $50 \mathrm{mg} / \mathrm{L} \mathrm{[20].}$ Thus, in the case of the rice straw-based rations the latter might have been highly relevant. The current reasoning implies that in the Panola based rations, the issue of $\mathrm{N}$ supply to rumen bacteria was not relevant. Finally, the current data do not support the idea that nitrate negatively affects the growth performance with a nitrate induced reduction of rumen propionate formation $[21,22]$. Needless to mention that the afore mentioned notions concerning the underlying mechanism on the observed nitrate induced improvement of FCR are speculative and that further studies are required for confirmation.

In the current experiment, neither DM-intake nor nutrient digestibility was influenced by $\mathrm{RS} \times \mathrm{N}$. Thus, it is difficult to see that the improved growth performance of the meat goats fed rice straw can be explained by DM intake or the total tract digestibility of nutrients. However, high-nitrate as such increased overall DM intake when the goats were fed rice straw, but quantitatively the effect was rather small when compared with low-nitrate (i.e. 3\%). It therefore appears that, with the exception of $\mathrm{N}$, high versus low nitrate did not affect the amounts of nutrients available to support maintenance and growth of the meat goats. The current trial does not provide clues to explain the stimulatory effect of nitrate on DM intake but [5] has reported that nitrate can cause a reduction in heat production. Since the current study was conducted under tropical conditions, it can be speculated that a reduced heat production explains the somewhat greater DM intake when high nitrate was fed.

With the exception of ADF, apparent nutrient digestibility was found to be greater when the goats were fed Pangola hay instead of rice straw. Clearly, these results are in line with expectation because it is widely accepted that the digestibility of Pangola hay is superior to that of rice straw [23]. However, the ADF digestibility was found to be greater when the goats were fed rice straw. Surprisingly, NDF digestibility remained unchanged when high nitrate was fed. It can therefore be speculated that under high nitrate conditions, the fermentation of cellulose is enhanced. Perhaps, ingestion of the highnitrate rations affected the rumen ecosystem [19] and as such induced a greater fermentation of cellulose. Unfortunately, the current paper does not provide clues to substantiate the latter suggestion.

The current rations contained either 0.8 (low nitrate) or $1.2 \%$ of DM (high nitrate) and such values can be lethal in unadapted ruminants [24], but adaptation apparently enabled rumen bacteria to increase in numbers or increase their nitrite-reducing capacity. In the current study however, the animals were slowly adapted to increased levels of nitrate, $3.2 \%$ or $4.8 \%$ which most likely enabled the rumen bacteria to sufficiently increase their capacity to reduce nitrite [5]. 
Moreover, in the case the current nitrate load is expressed as $\mathrm{g} / \mathrm{kg}^{0.75} / \mathrm{d}$, values are calculated to be 0.6 and $0.9 \mathrm{~g} \mathrm{NO}_{3}^{-} / \mathrm{kg}^{0.75} / \mathrm{d}$ for the low- and high nitrate rations, respectively. A considerably greater dosage (i.e. $1.6 \mathrm{~g} \mathrm{NO}_{3}^{-} / \mathrm{kg}^{0.75} / \mathrm{d}$ ) in their methane mitigating rations and they reported slightly elevated levels of methemoglobin [5]. It therefore appears that the nitrate levels used in the current study can be considered non-toxic.

\section{CONCLUSION}

The replacement of soybean meal by nitrate improved the growth performance of meat goats fed rations based on rice straw, but not Pangola hay.

\section{CONFLICT OF INTEREST}

We certify that there is no conflict of interest with any financial organization regarding the material discussed in the manuscript.

\section{ACKNOWLEDGMENTS}

The authors would like to express their most sincere thanks to Thailand Research Fund (TRF) through the Royal Golden Jubilee (PHD 0242554) for providing scholarship for the second author and provision of research funds and Suranaree University of Technology for providing laboratories and facilities supporting this research.

\section{REFERENCES}

1. Patra AK. Recent advances in measurement and dietary mitigation of enteric methane emissions in ruminants. Front Vet Sci 2016;3:39. https://doi.org/10.3389/fvets.2016.00039

2. Moss AR, Jouany JP, Newbold J. Methane production by ruminants: its contribution to global warming. Ann Zootech 2000;49:231-53. https://doi.org/10.1051/animres:2000119

3. Guyader J, Eugène M, Meunier B, et al. Additive methanemitigating effect between linseed oil and nitrate fed to cattle. J Anim Sci 2015;93:3564-77. https://doi.org/10.2527/jas.20148196

4. Nolan JV, Hegarty RS, Hegarty J, Godwin IR, Woodgate R. Effects of dietary nitrate on fermentation, methane production and digesta kinetics in sheep. Anim Prod Sci 2010;50:801-6. https://doi.org/10.1071/AN09211

5. van Zijderveld SM, Gerrits WJJ, Dijkstra J, Newbold JR, Hulshof RBA, Perdok HB. Persistency of methane mitigation by dietary nitrate supplementation in dairy cows. J Dairy Sci 2011;94:4028-38. https://doi.org/10.3168/jds.2011-4236

6. Li L, Davis J, Nolan J, Hegarty R. An initial investigation on rumen fermentation pattern and methane emission of sheep offered diets containing urea or nitrate as the nitrogen source. Anim Prod Sci 2012;52:653-8. https://doi.org/10.1071/AN11 254

7. Lewis D. The metabolism of nitrate and nitrite in the sheep. 2 . Hydrogen donators in nitrate reduction by rumen microorganisms in vitro. Biochem J 1951;49:149-53. https://doi. org/10.1042/bj0490149

8. Dijkstra J, France J, Davies DR. Different mathematical approaches to estimating microbial protein supply in ruminants. J Dairy Sci 1998;81:3370-84. https://doi.org/10.3168/ jds.S0022-0302(98)75902-8

9. Leng RA, Nolan JV. Symposium: protein nutrition of the lactating dairy cow. Nitrogen metabolism in the rumen. J Dairy Sci 1984;67:1072-89.

10. Troy SM, Duthie CA, Hyslop JJ, et al. Effectiveness of nitrate addition and increased oil content as methane mitigation strategies for beef cattle fed two contrasting basal diets. J Anim Sci 2015;93:1815-23. https://doi.org/10.2527/jas.2014-8688

11. Ungerfeld EM, Kohn RA. The role of thermodynamics in the control of ruminal fermentation. In: Sejrsen K, Hvelplund T, Nielsen MO, editors. Ruminant physiology: digestion, metabolism and impact of nutrition on gene expression, immunology and stress. Wageningen, Netherlands: Wageningen Academic Publishers; 2006. pp. 55-85.

12. Goodrich RD, Garrett JE, Gast DR, Kirick MA, Larson DA, Meiske JC. Influence of monensin on the performance of cattle. J Anim Sci 1984;58:1484-98. https://doi.org/10.2527/ jas1984.5861484x

13. Park T, Meulia T, Firkins JL, Yu Z. Inhibition of the rumen ciliate Entodinium caudatum by antibiotics. Front Microbiol 2017;8:1189. https://doi.org/10.3389/fmicb.2017.01189

14. AOAC International. Official methods of analysis. 15th ed. Washington DC, USA: AOAC International; 2000.

15. Van Soest PJ, Robertson JB, Lewis BA. Methods for dietary fiber, neutral detergent fiber, and nonstarch polysaccharides in relation to animal nutrition. J Dairy Sci 1991;74:3583-97. https://doi.org/10.3168/jds.S0022-0302(91)78551-2

16.SAS Institute Inc. SAS user's guide: statistic, version 5 edition. Cary, NC, USA: SAS Institute; 1996.

17. Jouany JP. Effect of rumen protozoa on nitrogen utilization by ruminants. J Nutr 1996;126(Suppl 4):1335S-46S. https:// doi.org/10.1093/jn/126.suppl_4.1335S

18. Borucki Castro SI, Phillip LE, Lapierre H, Jardon PW, Berthiaume R. Ruminal degradability and intestinal digestibility of protein and amino acids in treated soybean meal products. J Dairy Sci 2007;90:810-22. https://doi.org/10.3168/jds.S00220302(07)71565-5

19.Latham EA, Anderson RC, Pinchak WE, Nisbet DJ. Insights on alterations to the rumen ecosystem by nitrate and nitrocompounds. Front Microbiol 2016;7:228. https://doi.org/ 10.3389/fmicb.2016.00228

20.Satter LD, Slyter LL. Effect of ammonia concentration on 
rumen microbial protein production in vitro. Br J Nutr 1974; 32:199-208. https://doi.org/10.1079/BJN19740073

21. Yang WZ, Benchaar C, Ametaj BN, Chaves AV, He ML, McAllister TA. Effects of garlic and juniper berry essential oils on ruminal fermentation and on the site and extent of digestion in lactating cows. J Dairy Sci 2007;90:5671-81. https://doi.org/10.3168/jds.2007-0369

22. Guyader J, Eugène $M$, Doreau $M$, et al. Nitrate but not tea saponin feed additives decreased enteric methane emissions in nonlactating cows. J Anim Sci 2015;93:5367-77. https:// doi.org/10.2527/jas.2015-9367

23. Suzuki T, Phaophaisal I, Pholsen $\mathrm{P}$, et al. In vivo nutritive value of pangola grass (Digitaria eriantha) hay by a novel indirect calorimeter with a ventilated hood in Thailand. Jpn Agric Res Q 2008;42:123-9. https://doi.org/10.6090/jarq.42.123

24. Bruning-Fann CS, Kaneene JB. The effects of nitrate, nitrite, and n-nitroso compounds on animal health. Vet Hum Toxicol 1993;35:237-53. 